\title{
Papel de las células dendríticas en la infección por el virus dengue: blancos de replicación y respuesta inmune
}

\author{
Jahnnyer Martínez, Juan C. Hernández y Silvio Urcuqui-Inchima
}

\section{Role of dendritic cells in infection by dengue virus: targets for replication and immune response}

Dengue fever, caused by dengue virus (DENV) infection, is one of the most important diseases in the world, not only due to the high morbidity/mortality rates it causes, but also because of its great economic and social impact in tropical/subtropical countries. DENV infection has a wide range of clinical manifestations ranging from asymptomatic infection or infection with mild symptoms to severe dengue that can lead to death. At present, no etiological treatment or effective globally distributed vaccine against the four DENV serotypes exists. Despite great efforts made to understand the mechanism associated with DENV disease pathogenesis the causes leading to severe dengue presentation have not been clarified. Some hypotheses seek to give a biological and physiological explanation to the clinical manifestations that appear during the infection. Based on the evidence that after contact with dendritic cells DENV alters the functionality of these cells, this review aims to describe the most relevant findings regarding the importance of dendritic cells in the context of DENV infection and progression of the illness.

Key words: Dengue virus; innate immunity; dendritic cells; immunopathogenesis.

Palabras clave: Virus dengue; inmunidad innata; células dendríticas; inmunopatogénesis.

\section{Introducción}

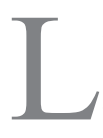

a enfermedad causada por el virus dengue (DENV) es endémica en más de 100 países del mundo y la Organización Mundial de la Salud (OMS) estima que aproximadamente $40 \%$ de la población mundial se encuentra en riesgo de ser infectada por el virus (www.who. int/mediacentre/factsheets/fs117/en/). La diseminación del virus está directamente relacionada con la distribución geográfica de sus vectores biológicos, principalmente mosquitos hembra de las especies Aedes aegypti y Aedes albopictus, siendo el primero, el de mayor distribución en zonas endémicas alrededor del mundo. Por su parte, A. Albopictus es un vector secundario implicado en la propagación del virus dentro del continente asiático y algunas regiones de Europa, lo cual conlleva a un aumento de la tasa de incidencia de la infección ${ }^{1,2}$.

El DENV es el Flavivirus de mayor impacto en la salud pública mundial y actualmente el dengue es la enfermedad viral transmitida por artrópodos más importante del planeta $^{3}$. Se estima una tasa de infección de 50-100 millones de personas infectadas alrededor del mundo, de los cuales, unos 500 mil casos progresan a dengue grave, anualmente. Si bien el dengue afecta a individuos en cualquier rango de edad, es una de las causas principales de hospitalización en niños bajo 15 años de edad ${ }^{4}$. El cuadro clínico de la infección normalmente cursa con una enfermedad benigna, y aunque no es claro el mecanismo exacto que genera una rápida progresión a las formas patológicas graves, existe evidencia que sugiere un efecto conjunto de tanto factores intrínsecos del virus, como del hospedero, en particular, la desregulación de la respuesta inmune ${ }^{5,6}$.

\section{Virus dengue y ciclo de replicación}

Se han descrito cuatro serotipos infectantes de DENV para los humanos, los que presentan una homología genética de alrededor de $70 \%$. Pertenece a la familia Flaviviridae y es un virus envuelto con genoma ARN monocatenario de polaridad positiva $[\operatorname{ssRNA}(+)]$ que codifica para tres proteínas estructurales $(C$, prM, E) y siete no estructurales (NS1, NS2A, NS2B, NS3, NS4A, NS4B y NS5) (Figura 1), involucradas en la replicación del ARN, el ensamblaje del virus y la modulación de la respuesta inmune de la célula hospedera ${ }^{7-10}$ (Tabla 1). Múltiples monómeros de la proteína $\mathrm{C}$ encapsidan el ARN viral para formar la nucleocápside ${ }^{11,12}$, la que está rodeada por una bicapa lipídica de origen celular donde se encuentran ancladas las proteínas M (matriz) y E (envoltura $)^{13}$. La proteína $\mathrm{E}$ es de especial importancia para el reconocimiento y unión a los receptores que median la entrada del virus a la célula blanco ${ }^{4}$, por endocitosis mediada por receptor; así inicia su ciclo de replicación.

Hasta el momento se ha determinado que varios tipos de moléculas actúan como receptores; siendo DC-SIGN
Universidad de Antioquia UdeA, Medellín, Colombia. Facultad de Medicina, Grupo Inmunovirología (JMM, JCH, SUI) Universidad Cooperativa de Colombia. Medellín, Colombia.

Facultad de Medicina, Infettare (JCH).

Los autores declaran no tener conflicto de intereses.

Estudio financiado por Colciencias, proyecto № 111556933443 y Universidad de Antioquia.

Recibido: 28 de febrero de 2017 Aceptado: 27 de marzo de 2017

Correspondencia a: Silvio Urcuqui-Inchima silvio.urcuqui@udea.edu.co 


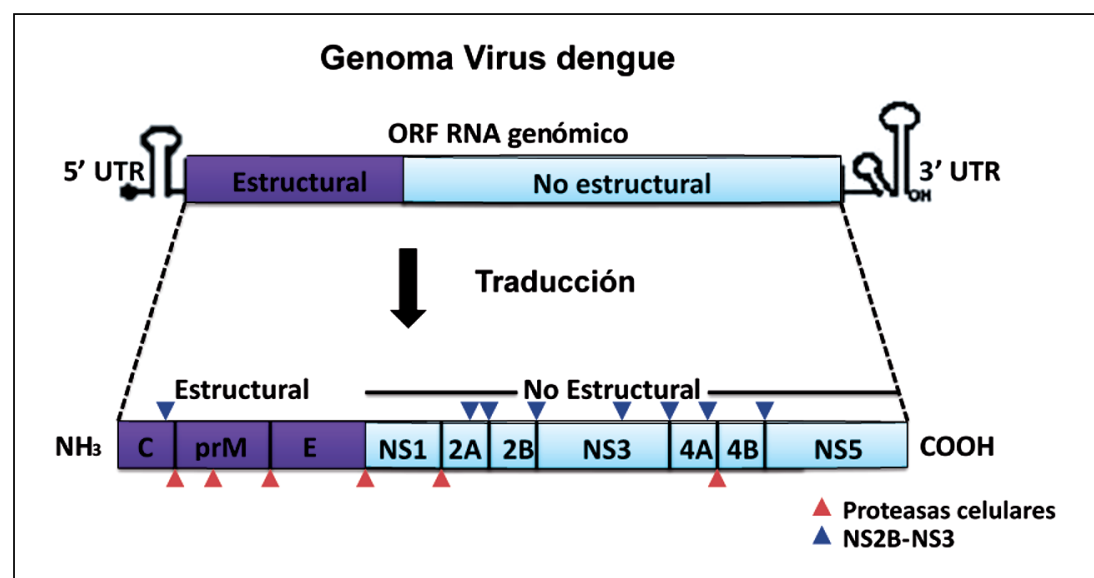

Figura 1. Representación esquemática de la estructura genómica del virus. En la parte superior se representa el genoma viral, indicando las regiones (UTR) no codificantes en los extremos 5' y 3'; La región codificante (ORF). En la parte inferior se representa la poliproteína, generada luego de la traducción del ARN viral, la cual es luego procesada por proteasas celulares (triángulo en rojo) y virales (triángulo en azul).

(dendritic cell-specific intercelular adhesion molecule 3-grabbin non-integrin), un receptor tipo lectina altamente expresado en células presentadoras de antígeno, el receptor mejor caracterizado ${ }^{14}$. Luego de la entrada del virus a la célula, consecuencia del pH ácido del endosoma, ocurre la fusión de membranas, etapa necesaria para la liberación de la cápside en el citoplasma y la desencapsidación. Acto seguido, el genoma viral es reconocido por los ribosomas y traducido en una poliproteína, posteriormente hidrolizada por la acción de proteasas virales y celulares para generar las 10 proteínas virales ${ }^{15}$. La replicación y ensamblaje de la nueva progenie viral ocurre en la membrana del retículo endoplásmico, dando origen a la formación de partículas virales inmaduras. Éstas son transportadas a través de la vía secretoria y durante su paso por el compartimento Trans-Golgi, se da la maduración de la partícula viral y finalmente es liberada al medio extracelular ${ }^{15}$.

\section{Patogénesis y formas clínicas del dengue}

El mayor porcentaje de infecciones por DENV son asintomáticas, pero aquellos individuos que desarrollan la enfermedad se han agrupado en pacientes con dengue con o sin signos de alarma previamente conocido como fiebre por dengue (sigla en inglés DF) y pacientes con dengue grave previamente conocido como fiebre del dengue hemorrágico (sigla en inglés DHF) y síndrome de choque por dengue (sigla en inglés DSS) ${ }^{16}$. El mecanismo de patogénesis del DENV aún no es muy claro, pero la mayoría de los reportes apuntan a una enfermedad mediada por la respuesta inmune del hospedero más que una enfermedad causada por el mismo virus ${ }^{17,18}$.

Dado que las principales células blanco de la replicación de DENV son células dendríticas (sigla en inglés DC), monocitos y macrófago, en los últimos años se ha postulado que la infección de esas células conlleva a la activación de eventos inmunes que podrían explicar la ocurrencia de un dengue grave. Por ejemplo, su infección puede inducir, además de la activación de los linfocitos $\mathrm{T} \mathrm{CD}^{+}$y CD8 ${ }^{+}$, la producción desproporcionada de citoquinas pro- $y$ anti-inflamatorias tales como TNF- $\alpha$, IL-2, IL-6, IL1- $\beta$, IL-8 e IL-10, que promueven la progresión de la enfermedad ${ }^{19,20}$. Dichas citoquinas se han respon-

\begin{tabular}{|c|c|c|}
\hline NS1 & $\begin{array}{l}\text { - Indicador de replicación temprana en Flavivirus } \\
\text { - Posiblemente participa en la replicación del ARN }\end{array}$ & $(7,8)$ \\
\hline NS2A & $\begin{array}{l}\text { - Inhibe la vía de señalización del interferón tipo } 1 \text { (IFN I) al reducir la activación de la proteína para la transducción } \\
\text { de señal y activación de la transcripción (STAT) }\end{array}$ & (8) \\
\hline NS2B & - Cofactor de NS3 para formar la serina-proteasa viral, encargada de la hidrólisis de otras proteínas del virus & (61) \\
\hline NS4A & $\begin{array}{l}\text { - Probablemente involucrada en la replicación del ARN } \\
\text { - Induce reordenamientos de membranas celulares a favor de la replicación del virus } \\
\text { - Bloqueo de señalización de IFN I }\end{array}$ & (64) \\
\hline
\end{tabular}


sabilizado del aumento paulatino de la permeabilidad vascular que conlleva a la pérdida de plasma y fluidos, ocasionando uno de los signos más importantes como es la hemoconcentración, además del desorden en la hemostasis, que resulta en cambios vasculares, trombocitopenia y coagulopatía.

En pacientes con DF se han reportado concentraciones plasmáticas elevadas de IL-12, pero esta citoquina está totalmente ausente en pacientes con DHF. Es decir, la IL-12 podría estar jugando un papel importante en la prevención de los estadios graves de la enfermedad, manteniendo constante una respuesta tipo Th1 ${ }^{21}$.

Recientemente también se sugirió que la elastasa, una proteinasa secretada por neutrófilos activados, podría participar en la gravedad del dengue ${ }^{21}$; la elastasa puede facilitar el daño endotelial mediado por neutrófilos, activar el complemento, el sistema de coagulación y el fibrinolítico.

También se ha reportado que una vez el sistema inmune es expuesto al DENV durante una infección primaria, se produce la activación y proliferación de una gran cantidad de linfocitos T resultando en una respuesta inmune específica contra los antígenos producidos por el serotipo infectante. Dicha defensa es específica contra el serotipo causante de la primo-infección, pero no contra los otros tres serotipos de DENV descritos. Por lo tanto, la reinfección por otro serotipo, que posee determinantes antigénicos distintos, ocasionará una respuesta inmune inespecífica y exacerbada producida por los linfocitos $\mathrm{T}$ de memoria generados durante la infección primaria, lo cual determinaría la aparición de manifestaciones más graves de la enfermedad. En otras palabras, la afinidad de los linfocitos T por el DENV infectante durante una primo-infección es alta, pero esa afinidad cambia cuando se trata de un serotipo diferente. Este fenómeno se ha denominado "pecado original antigénico" y puede jugar un papel importante en la inmunopatogénesis del dengue grave, ya que dicha respuesta puede suprimir o retrasar la eliminación del virus, llevando a un incremento en la carga viral y en la inmunopatogénesis de la infección ${ }^{22}$. Igualmente, reportes recientes han demostrado que la proteína viral NS1 posee alta capacidad inmunogénica, contribuyendo mediante distintos mecanismos, con la aparición del fenómeno de permeabilidad vascular por afectación de las células endoteliales, relacionándola directamente con la inmunopatogénesis del dengue grave $^{21,23,24}$. Pero cualquiera que sea el mecanismo por el cual sobreviene la hemorragia, en última instancia, el blanco es el endotelio, convirtiéndolo en un tejido que juega un papel muy importante en la patogénesis del dengue grave.

La hipótesis más aceptada actualmente y que explica de una mejor manera la patogénesis del dengue grave, es la amplificación dependiente de anticuerpos (sigla en inglés
ADE). Ésta establece básicamente que durante infecciones secundarias con un serotipo diferente al de la primera infección, concentraciones plasmáticas pre-existentes de anticuerpos, sub-neutralizantes y no protectores, aumentan la replicación de un serotipo diferente por medio de receptores $\mathrm{Fc}$ gamma $(\mathrm{Fc} \gamma \mathrm{R})$, especialmente en monocitos y macrófagos ${ }^{25}$.

\section{Papel de las células dendríticas en la infección por dengue}

Las DC son células presentadoras de antígeno (CPA), que residen y/o migran a través de los tejidos que componen el sistema inmune, capaces de detectar y controlar la presencia de patógenos invasores mediante la activación de sus funciones implicadas en la respuesta inmunes innatas. Además, participan en el establecimiento de la respuesta inmune adaptativa. Estas células se caracterizan por su expresión variable, en condiciones basales, de la integrina CD11c y moléculas del complejo mayor de histocompatibilidad (CMH) clase II $^{26,27}$. En humanos se conocen dos poblaciones de DC: las DC mieloides o convencionales (sigla en inglés $\mathrm{mDC}$ ), en las que se incluyen las siguientes subpoblaciones: DC derivadas de monocitos (sigla en inglés MDDC), DC intersticiales (sigla en inglés iDC) y las células de Langerhans (sigla en inglés LC); y las DC plasmacitoides (sigla en inglés pDC) que son las principales productoras de interferón alfa (IFN- $\alpha)^{28,29}$. En condiciones basales y en ausencia de estímulo, las $\mathrm{mDC}$ exhiben un fenotipo inmaduro y se conocen como DC inmaduras (imDC), las que se caracterizan por presentar capacidad fagocítica eficiente, pero una baja expresión de componentes del Complejo Mayor de Histocompatibilidad clase I y II, y moléculas co-estimuladoras (CD80 y CD86), limitando su función como células presentadoras de antígeno. Luego de su estimulación entran en un proceso de maduración (matDC), caracterizado por un aumento en su capacidad migratoria hacia los órganos linfoides secundarios y su habilidad como $\mathrm{CPA}^{27}$. Esos cambios fenotípicos y funcionales permiten a las DC inducir la activación y proliferación de linfocitos $\mathrm{B}$ y $\mathrm{T}$, lo que conlleva al establecimiento de una respuesta inmune específica ${ }^{27}$. Tanto las mDC como las pDC están asociadas con la respuesta inmune innata antiviral y la presentación antigénica para el establecimiento de la respuesta inmune adaptativa.

Como se explicó previamente, DC-SIGN es una de las principales moléculas implicadas en la entrada del DENV a la célula blanco. Inicialmente, cuando el mosquito vector hembra infectado pica al hospedero, introduce el virus y las primeras células en infectarse son las $\mathrm{mDC}^{28}$. Esto es de vital importancia si se tiene en cuenta que las DC juegan un papel crucial en la activación, tanto de la respuesta inmune innata como la adaptativa ${ }^{28}$. Estas células actúan 
como CPA profesionales gracias a su gran capacidad para procesar y presentar una gran cantidad de moléculas derivadas de patógenos y para amplificar la respuesta inmunológica. Las DC se encuentran distribuidas en todo el cuerpo humano, ubicadas en sitios estratégicos donde actúan como células "centinela" para detectar la entrada de patógenos ${ }^{28}$. Aunque las imDC no poseen la capacidad para hacer una presentación antigénica eficiente a los linfocitos $\mathrm{T}$, son células que poseen una gran habilidad para captar antígenos presentes en su microambiente. Así, las imDC podrían jugar un papel importante en las etapas tempranas de la infección por DENV, tal como se discute a continuación.

\section{Células dendríticas intersticiales (iDC) y células de Langerhans (LC) como blancos tempranos de la infección por DENV}

Está bien establecido que la función de las DC es la captura y procesamiento de péptidos inmunogénicos para llevarlos a los nódulos linfoides y presentarlos a los linfocitos $\mathrm{T}$ en el contexto de moléculas del CMH clase I y clase $\mathrm{II}^{30}$. A partir del progenitor mieloide $\mathrm{CD} 34+$, ocurre la diferenciación de dos fenotipos distinto de imDC: las CD $11 \mathrm{c}^{+} \mathrm{CD} \mathrm{a}^{+}$(LC en epidermis) y las CD11 $\mathrm{c}^{+} \mathrm{CD} 1 \mathrm{a}^{-}$ (iDC en dermis y otros tejidos) $)^{31,32}$.

Hasta hace algunos años, se consideraba que los fagocitos mononucleares, monocitos y macrófagos eran las principales células blanco de la infección por DENV ${ }^{33,34}$. Sin embargo, si se tiene en cuenta que el DENV es inoculado a través de la piel durante el proceso de alimentación del mosquito infectado, existía la posibilidad de que células ubicadas en dicho tejido sean las primeras en entrar en contacto con el virus. Taweechaisupapog y cols., lo demostraron al inyectar DENV-2 vía intradérmica en ratones y observar una alta actividad migratoria de LC, después de $24 \mathrm{~h}$ de infección ${ }^{35}$. Esos resultados fueron luego corroborados en LC humanas, por Wu y cols. ${ }^{36}$. Sin embargo, estudios adicionales podrían establecer el verdadero papel de las DC durante la infección con DENV y permitirían orientar nuevas estrategias terapéuticas con miras a bloquear no sólo la entrada del virus en dichas células sino la propagación de la infección a otros tejidos durante las etapas tempranas.

Se ha demostrado que las MDDC, son susceptibles a la infección por $\mathrm{DENV}^{36}$, y de hecho son hasta 10 veces más permisivas a la infección por DENV que monocitos o macrófagos, in vitro ${ }^{28}$. Además, estudios realizados en explantes de piel, muestran que la gran mayoría de las DC migratorias son capaces no sólo de soportar la replicación viral, sino que la infección por DENV también promueve su maduración, según la expresión de marcadores como CD83, CD11b y HLA-DR, y la producción de IFN- $\alpha$ y TNF- $\alpha^{37,38}$. De este modo, las
MDDC podría tener un papel dual durante la infección con DENV; actuar como células centinelas y actores primordiales para generar una respuesta inmune contra el virus, y ser uno de los principales blancos y medios de propagación de la infección en el hospedero. A partir de estos hallazgos y a falta de investigaciones que logren esclarecer con exactitud el rol de esta subpoblación de DC en el desarrollo y resolución de la infección, surge la siguiente pregunta ¿qué tan benéfica es la participación y activación de las MDDC durante la infección con DENV? Futuras investigaciones en las que se pueda esclarecer la importancia de las MDDC en la patogénesis del dengue son necesarias para entender mejor la interacción entre el DENV y el hospedero.

\section{Papel de las células dendríticas mieloides (mDC) y células dendríticas plasmacitoides (pDC) en la infección por DENV}

Las pDC (Lin1-CD11c-CD14-CD123 $3^{\text {high }}$ ) se distribuyen principalmente en tejido linfoide asociado a mucosas y en regiones ricas en linfocitos $\mathrm{T}$ de tejidos linfoides secundarios $^{29}$. Las $\mathrm{mDC}\left(\mathrm{Lin} 1^{-} \mathrm{CD} 11 \mathrm{c}^{\text {high }} \mathrm{CD} 14\right.$ ) se encuentran en áreas ricas en linfocitos $\mathrm{T}$ pero en tejidos no linfoides ${ }^{39,40}$. Se ha reportado que la infección de $\mathrm{pDC}$ y $\mathrm{mDC}$ por DENV estimula no sólo la respuesta innata dependiente de receptores tipo Toll (TLR)7, TLR3, MDA5 y RIG-I e induce la secreción de IFN tipo I; sino que también contribuye a que otras poblaciones de células sean resistentes a una subsecuente infección por $\mathrm{DENV}^{25}$. Recientemente se demostró que las $\mathrm{mDC}$ son altamente permisivas a la infección por DENV, consecuencia de un aumento significativo en la expresión de DC-SIGN ${ }^{39}$. No se observó el mismo comportamiento en las pDC expuestas al virus y bajo las mismas condiciones, aunque los investigadores sí detectaron la presencia del genoma viral por RCP-TR. Posiblemente esto se debe a que, en este tipo de células, el DENV se encuentra principalmente en compartimentos endosomales $^{41}$. Esos resultados sugieren que las pDC internalizan el virus, pero no tienen capacidad para soportar la replicación y producción de nueva progenie viral $^{39}$. Lo interesante de todo esto es que se observó que la producción de TNF- $\alpha$ e IFN- $\alpha$ era 10 veces más alta en $\mathrm{pDC}$ que en $\mathrm{mDC}$; la producción de esas citocinas fue independiente de la replicación viral, pero dependiente de la vía de TLR7 y de la acidificación endosomal ${ }^{39}$. Por el contrario, en $\mathrm{mDC}$ la producción de citocinas es dependiente de la replicación viral. Igualmente se ha observado que las pDC no sólo detectan las células infectadas por DENV a través de un contacto directo célula a célula, sino que también reconocen partículas virales inmaduras e inducen una mayor secreción de IFN, comparado con partículas virales maduras ${ }^{25,42}$. El conjunto de esos resultados sugiere que las $\mathrm{mDC}$ son blanco importante para la 
replicación del DENV y participan en el establecimiento de una respuesta contra la infección. Por el contrario, dado que las pDC no son permisivas a la infección y replicación de DENV, posiblemente les permite no sólo combatir la infección sin sufrir las consecuencias de la evasión inmune mediada por proteínas virales, sino también una mayor activación de otras células inmunes mediante la secreción de IFN tipo I y citoquinas.

En pacientes con dengue se observó que el número absoluto y la frecuencia de $\mathrm{mDC}$ circulantes en sangre disminuye durante la fase aguda de la enfermedad o a medida que aumentaba la gravedad de la enfermedad ${ }^{43}$. En niños con enfermedad leve por DENV, se observó una tendencia al alza en la frecuencia de pDC en sangre periférica durante la infección aguda por DENV, comparado con pacientes estables; sin embargo, en niños que luego desarrollaron DHF acompañado de un aumento en la viremia, se reportó una disminución en los niveles circulantes de pDC y la respuesta inmune mediada por IFN tipo I fue poco eficiente ${ }^{25,43}$. Esos resultados posiblemente sugieren que esas dos subpoblaciones de DC juegan un papel muy importante durante el proceso infeccioso por DENV y en la patogénesis del dengue.

La participación de los receptores de reconocimiento de patrones, como los $T L R$, en la activación de la respuesta inmune innata contra DENV también ha sido reporta$\mathrm{da}^{44,45}$. Igualmente nosotros reportamos en mDC y pDC obtenidas de pacientes con DF, una mayor expresión de TLR3 y TLR9 en fases tempranas de la infección; por el contrario, en pacientes con manifestaciones graves de la enfermedad se evidenció una disminución en la expresión de TLR3 y TLR9 ${ }^{46}$.

Además, observamos que las DC provenientes de pacientes con DHF expresaban mayores niveles de TLR2 comparadas con DC obtenidas de pacientes con DF Estos hallazgos sugieren que una expresión diferencial de los TLR, en particular TLR3 y TLR9, en DC durante la infección por DENV, favorecería la producción de IFN, lo cual podría jugar un papel muy importante en la progresión del dengue.

\section{DC y la potenciación de la infección mediada por anticuerpos (ADE) en la infección por} DENV

Como se mencionó previamente, varios tipos de células primarias humanas y líneas celulares se han reportado como permisivas a la infección por DENV, incluyendo monocitos/macrófagos, hepatocitos, células endoteliales, células neuronales, DC, etc. En modelos murinos y en humanos se ha confirmado que tanto macrófagos como DC son blanco de la infección; además, las DC primarias consideradas como blancos tempranos para la replicación del virus, son las más susceptibles a la infección directa con $\mathrm{DENV}^{36,47}$. Hasta hace algunos años, la infección por DENV en DC había sido estudiada principalmente en MDDC. En esos estudios se demostró la gran importancia del receptor DC-SIGN para la internalización del virus $^{28}$. Sin embargo, diversos estudios han demostrado que anticuerpos sub-neutralizantes anti-DENV, pueden potenciar la entrada e infección de DENV, fenómeno conocido como "potenciación de la infección mediada por anticuerpos", más comúnmente conocido como $\mathrm{ADE}$, lo que incrementa tanto la viremia como la gravedad de la enfermedad ${ }^{25,27,48}$. La expresión de Fc $\gamma \mathrm{R}$ determina la susceptibilidad de las células al ADE durante la infección por DENV, ya que permiten la captación de los inmunocomplejos virus-anticuerpos. Las células mieloides expresan las tres clases de receptores Fc gamma descritos en humanos (Fc $\gamma R I / C D 64$, Fc $\gamma R I I / C D 32$ y Fc $\gamma$ RIII/ CD16) ${ }^{27,49}$. Los inmuno-complejos (DENV-anticuerpos) pueden ser captados por Fc $\gamma R I$ y Fc $\gamma R I^{50}$. Boonnak y cols., mostraron que en DC las isoformas FcyRlla y FcyRllb son capaces de unir los inmuno-complejos de DENV de forma similar, pero sólo los FcyRlla permiten la fagocitosis e internalización del virus; consistente con esos hallazgos, el bloqueo de los FcyRlla, pero no de los FcyRllb, limitó el ADE en MDDC ${ }^{51,52}$. Igualmente se observó que, si bien las imDC y matDC expresan niveles similares de FcyRlla, sólo las matDC son permisivas al DENV a través del ADE. Esto posiblemente está relacionado al hecho que las imDC expresan altos niveles de DC-SIGN, por lo que el DENV no requiere FcyR para la unión o entrada del virus ${ }^{51}$, a diferencia de las matDC ${ }^{53}$. Las matDC expresan principalmente FcyRlla y FcyRllb. Se ha observado que la captación de inmuno-complejos por Fc $\gamma$ Rllb, un receptor inhibitorio, no permite la fagocitosis e internalización del virus, dependiente de $\mathrm{ADE}^{52}$. Esto ha conllevado a implementar el uso de anticuerpos monoclonales contra DENV que sean reconocidos por esa isoforma, como una alternativa terapéutica potencial para evitar la progresión de la enfermedad a las formas graves. Igualmente se ha reportado que el ADE conlleva a un incremento en la producción de TNF- $\alpha$ e IL-6, a un aumento de la permeabilidad vascular, a un aumento en la producción viral y a la transmisibilidad del virus ${ }^{51}$.

Como se mencionó previamente, las imDC no son permisivas a la infección dependiente de anticuerpos, aunque sí tienen la capacidad de unir inmuno-complejos. A la fecha se desconoce las consecuencias de ese fenómeno en imDC infectadas por DENV. Recientemente evaluamos dicho fenómeno y pudimos establecer que la unión de inmuno-complejos neutralizantes promueve la maduración total de las imDC e induce una producción balanceada de citocinas pro-inflamatorias ${ }^{54}$. Adicionalmente, se observó que el efecto de los inmuno-complejos es dependiente de la unión a FcyRlla. Estos resultados demuestran que, 
aunque los inmuno-complejos de DENV no conllevan a $\mathrm{ADE}$ en imDC, su presencia sí puede alterar el fenotipo y el patrón de expresión de citocinas en dichas células.

\section{Consecuencias de la infección de DC por DENV}

Las DC han adquirido vital importancia durante la infección por DENV debido a su capacidad para captar y presentar antígenos virales, desencadenando la activación de la respuesta inmune, que puede conllevar a la resolución de la infección o a un aumento de la gravedad del dengue $^{19,21}$. Esto va muy de la mano del nivel de expresión de los receptores DC-SIGN y de FcyRII para el reconocimiento, internalización y replicación del virus en imDC y matDC, respectivamente. Sin embargo, algunos autores describen que la activación de las DC infectadas es menor, comparada con la activación de células adyacentes no infectadas $^{36,37}$. Dado que las imDC infectadas con DENV presentan un menor grado de maduración, comparado con imDC adyacentes no infectadas, se ha propuesto que la infección de las DC tiene un efecto directo en la expresión de moléculas co-estimuladoras, lo que conllevaría a la activación de las DC adyacentes ${ }^{55}$. Esto podría estar relacionado con la apoptosis observada en DC infectadas por DENV, consecuencia de la replicación viral, lo que a la vez podría estar relacionado con la patogénesis del dengue $^{55,56}$. Otro aspecto importante a tener presente al momento de establecer los mecanismos implicados en la patogénesis del DENV y el papel de las DC en dicho proceso, es la expresión de metalo-proteinasas de matrix (sigla en inglés MMP), como MMP-2, MMP-9 y MMP-13. Existen reportes que muestran que las imDC infectadas por el DENV expresan altas concentraciones de esas proteínas, lo que conlleva a una disminución de la interacción celular por cambios en el ordenamiento de la actina del citoesqueleto, afectando la morfología de células endoteliales ${ }^{57}$. Esto podría estar sugiriendo una participación directa de las DC en el fenómeno de permeabilidad vascular descrito en la inmunopatogénesis de la enfermedad.

Con relación a la respuesta inmune adaptativa y DC, se conoce que durante el curso de la infección por DENV se presenta una sobreproducción de citoquinas, mediada principalmente por linfocitos $\mathrm{T}^{19}$, pero también se ha observado una disminución en la proliferación de esas células en respuesta a antígenos del DENV, lo que posiblemente conlleva a una presentación antigénica deficiente ${ }^{55,58}$. Linfocitos T y DC establecen interacciones a través de las moléculas ICAM3 y DC-SIGN, respectivamente, para lograr una correcta estimulación de linfocitos $\mathrm{T}$ y desencadenar una respuesta inmune eficiente. Teniendo en cuenta que la infección de DC por DENV disminuye la expresión de moléculas co-estimuladoras en su superficie, podría tener consecuencias en la alteración de la estimulación de linfocitos $\mathrm{T}$, dependiente de DC. Además se debe tener presente que DC infectadas y co-cultivadas con linfocitos $\mathrm{T}$, producen altas concentraciones de IL-10, TNF- $\alpha$ e IFN- $\alpha^{55}$. El TNF- $\alpha$ e IFN- $\alpha$ pueden generar la maduración de $\mathrm{DC}$ adyacentes, pero a la vez altas concentraciones de IL-10 puede desencadenar un fenotipo regulador de DC, disminuyendo la activación de la respuesta inmune, lo cual ha sido relacionado con la gravedad de la infección por DENV ${ }^{55}$. Por otra parte, los linfocitos $\mathrm{T}$ cumplen su función co-estimuladora de DC a través de CD40L, IL-6, IFN- $\gamma$ y TNF- $\alpha^{59}$. Esto es muy interesante porque recientemente se describió que las DC obtenidas de pacientes infectados con DENV producen gran cantidad de quimoquinas inducibles por IFN-y (CXCL9, CXCL10 y CXCL11), lo que influye directamente en la permeabilidad endotelial y, por ende, muy posiblemente en la patogénesis del $\mathrm{DENV}^{60}$. El conjunto de esos resultados indica que efectivamente las DC participan activamente no sólo en la infección por el DENV, sino que su activación altera el sistema inmune, lo cual promueve la secreción de citoquinas pro-inflamatorias, participando así en la permeabilidad vascular, observada en pacientes con dengue grave. Pero a pesar de la información recopilada, aún son necesarios nuevos estudios que permitan establecer con mayor claridad, la importancia de las DC en la patogénesis del DENV.

\section{Conclusión}

La enfermedad producida por la infección con DENV se ha convertido en los últimos años en un problema de salud pública mundial, debido principalmente a la existencia de cuadros graves que pueden conllevar a la muerte.

Las DC constituyen un importante componente de células de la inmunidad innata, capaces de generar comunicación con la inmunidad adaptativa, principalmente mediante el proceso de presentación antigénica. Debido a la participación de iDC como células blanco de activación e infección primaria por DENV, las DC juegan un papel protagónico en el curso de la infección y la inmunopatogénesis de la enfermedad. Así, la respuesta a la infección mediada por las DC, puede presentarse de manera directa, mediante la producción de diferentes tipos de citoquinas pro- y anti-inflamatorias e IFN tipo I, entre otros factores solubles; o de manera indirecta, mediante la activación de otros tipos celulares como linfocitos T y NK (natural killer), capaces de establecer una respuesta mucho más efectiva frente a la infección por DENV. Sin embargo, la exacerbación de esa respuesta, puede desencadenar situaciones adversas para el organismo, convirtiéndose en un factor importante en el desarrollo de la inmunopatogénesis de la infección.

Por tanto, es de vital importancia estudiar a fondo los 
posibles eventos que puedan desencadenarse en respuesta al contacto del DENV con las DC. Esto permitiría adquirir nuevos conocimientos que conlleven a una mejor comprensión de la relación virus-hospedero y a establecer la importancia de las DC en la progresión del dengue.

Agradecimientos. A Colciencias y Universidad de Antioquia, UdeA.

\section{Resumen}

El dengue, causada por el virus dengue (DENV), es una de las enfermedades más importantes no sólo por los altos índices de morbilidad/mortalidad, sino también por su gran impacto económico y social en los países de las regiones tropicales/subtropicales. La infección por el DENV cursa por un variado rango de manifestaciones clínicas que van desde una infección asintomática o con síntomas leves, hasta el dengue grave que puede ser fatal. En la actualidad, no se dispone de un tratamiento etiológico y tampoco de una vacuna eficaz mundialmente distribuida, contra los 4 serotipos del DENV. A pesar de los grandes esfuerzos orientados a entender el mecanismo asociado con la patogénesis de la enfermedad, aún no se ha logrado esclarecer de forma definitiva las causas que conllevan a las formas graves de enfermedad. Algunas hipótesis buscan dar una explicación biológica y fisiológica a las manifestaciones clínicas que se presentan durante la infección. Dado que una de ellas sugiere que luego del contacto con las células dendríticas el DENV altera su funcionalidad, la presente revisión tiene como objetivo describir los hallazgos más relevantes referentes a la importancia de dichas células en el marco de la infección por el DENV y progresión de la enfermedad.

\section{Referencias bibliográficas}

1.- Guha-Sapir D, Schimmer B. Dengue fever: new paradigms for a changing epidemiology. Emerg Themes Epidemiol 2005; 2 (1): 1.

2.- Farrar J, Focks D, Gubler D, Barrera R, Guzman M G, Simmons C, et al. Towards a global dengue research agenda. Trop Med Int Health 2007; 12 (6): 695-9.

3.- Carrington C V, Foster J E, Pybus O G, Bennett $\mathrm{S} N$, Holmes E C. Invasion and maintenance of dengue virus type 2 and type 4 in the Americas. J Virol 2005; 79 (23): 14680-7.

4.- da Fonseca B A, Fonseca S N. Dengue virus infections. Curr Opin Pediatr 2002; 14 (1): 6771.

5.- $\quad$ Lin C F, Lei H Y, Shiau A L, Liu H S, Yeh T M, Chen S H, et al. Endothelial cell apoptosis induced by antibodies against dengue virus nonstructural protein 1 via production of nitric oxide. J Immunol 2002; 169 (2): 657-64.

6.- Lei H Y, Yeh T M, Liu H S, Lin Y S, Chen S H, Liu C C. Immunopathogenesis of dengue virus infection. J Biomed Sci 2001; 8 (5): 377-88.

7.- García-Blanco M A, Vasudevan S G, Bradrick S S, Nicchitta C. Flavivirus RNA transactions from viral entry to genome replication. Antiviral Res 2016; 134: 244-9.

8.- Urcuqui-Inchima S, Patino C, Torres S, Haenni A L, Díaz F J. Recent developments in understanding dengue virus replication. Adv Virus Res 2010; 77: 1-39.

9.- Guabiraba R, Ryffel B. Dengue virus infection: current concepts in immune mechanisms and lessons from murine models. Immunology 2013; 141 (2): 143-56.

10.- Bressanelli S, Stiasny K, Allison S L, Stura E A, Duquerroy S, Lescar J, et al. Structure of a flavivirus envelope glycoprotein in its low-
pH-induced membrane fusion conformation. EMBO J 2004; 23 (4): 728-38.

11.- Ma L, Jones C T, Groesch T D, Kuhn R J, Post $\mathrm{C} B$. Solution structure of dengue virus capsid protein reveals another fold. Proc Natl Acad Sci U S A 2004; 101 (10): 3414-9.

12.- Chang C J, Luh H W, Wang S H, Lin H J, Lee S C, Hu S T. The heterogeneous nuclear ribonucleoprotein $\mathrm{K}$ ( $\mathrm{hnRNP} \mathrm{K}$ ) interacts with dengue virus core protein. DNA Cell Biol 2001; 20 (9): 569-77.

13.- Modis Y, Ogata S, Clements D, Harrison S C. Variable surface epitopes in the crystal structure of dengue virus type 3 envelope glycoprotein. J Virol 2005; 79 (2): 1223-31.

14.- Tassaneetrithep B, Burgess T H, GranelliPiperno A, Trumpfheller C, Finke J, Sun W, et al. DC-SIGN (CD209) mediates dengue virus infection of human dendritic cells. J Exp Med 2003; 197 (7): 823-9.

15.- Rodenhuis-Zybert I A, Wilschut J, Smit J M. Partial maturation: an immune-evasion strategy of dengue virus? Trends Microbiol 2011; 19 (5): 248-54.

16.- $\mathrm{WHO} / \mathrm{TDR}$. Dengue guidelines for diagnosis, treatment, prevention and control. 2013/06/14 ed. New Edition.Geneva: World Health Organization; 2009.

17.- Guzmán M G, Harris E. Dengue. Lancet 2014; 385 (9966): 453-65.

18.- Rothman A L. Immunity to dengue virus: a tale of original antigenic sin and tropical cytokine storms. Nat Rev Immunol 2011; 11 (8): 532-43.

19.- Pang T, Cardosa M J, Guzmán M G. Of cascades and perfect storms: the immunopathogenesis of dengue haemorrhagic fever-dengue shock syndrome (DHF/DSS). Immunol Cell Biol 2007; 85 (1): 43-5.

20.- Rothman A L. Immunology and immunopathogenesis of dengue disease. Adv Virus Res 2003; 60: 397-419.

21.- Basu A, Chaturvedi U C. Vascular endothelium: the battlefield of dengue viruses. FEMS Immunol Med Microbiol 2008; 53 (3): 287-99.

22.- Mongkolsapaya J, Dejnirattisai W, Xu XN, Vasanawathana S, Tangthawornchaikul N, Chairunsri A, et al. Original antigenic sin and apoptosis in the pathogenesis of dengue hemorrhagic fever. Nat Med 2003; 9 (7): 921-7.

23.- Modhiran N, Watterson D, Muller D A, Panetta A K, Sester D P, Liu L, et al. Dengue virus NS1 protein activates cells via Toll-like receptor 4 and disrupts endothelial cell monolayer integrity. Sci Transl Med 2015; 7 (304): 304ra142.

24.- Puerta-Guardo H, Glasner D R, Harris E. Dengue virus NS1 disrupts the endothelial glycocalyx, leading to hyperpermeability. PLoS Pathog 2016; 12 (7): e1005738.

25.- Schmid M A, Diamond M S, Harris E. Dendritic cells in dengue virus infection: targets of virus replication and mediators of immunity. Front Immunol 2014; 5: 647.

26.- Merad M, Sathe P, Helft J, Miller J, Mortha A. The dendritic cell lineage: ontogeny and function of dendritic cells and their subsets in the steady state and the inflamed setting. Annu Rev Immunol 2013; 31: 563-604.

27.- Santos Souza H F, da Silva Almeida B, Boscardin S B. Early dengue virus interactions: the role of dendritic cells during infection. Virus Res 2016; 223: 88-98.

28.- Navarro-Sánchez E, Despres P, Cedillo-Barron L. Innate immune responses to dengue virus. Arch Med Res 2005; 36 (5): 425-35.

29.- Liu Y J. Dendritic cell subsets and lineages, and their functions in innate and adaptive immunity. Cell 2001; 106 (3): 259-62. 
30.- Liu Y J, Kanzler H, Soumelis V, Gilliet M. Dendritic cell lineage, plasticity and crossregulation. Nat Immunol 2001; 2 (7): 585-9.

31.- Strunk D, Egger C, Leitner G, Hanau D, Stingl G. A skin homing molecule defines the Langerhans cell progenitor in human peripheral blood. J Exp Med 1997; 185 (6): 1131-6.

32.- Ito T, Inaba M, Inaba K, Toki J, Sogo S, Iguchi $\mathrm{T}$, et al. A CD1a+/CD11 c+ subset of human blood dendritic cells is a direct precursor of Langerhans cells. J Immunol 1999; 163 (3): 1409-19.

33.- Halstead S B, O’Rourke E J. Dengue viruses and mononuclear phagocytes. I. Infection enhancement by non-neutralizing antibody. J Exp Med 1977; 146 (1): 201-17.

34.- Gordon $\mathrm{S}$. The role of the macrophage in immune regulation. Res Immunol 1998; 149 (7-8): 685-8.

35.- Taweechaisupapong $S$, Sriurairatana $S$, Angsubhakorn S, Yoksan S, Bhamarapravati $\mathrm{N}$. In vivo and in vitro studies on the morphological change in the monkey epidermal Langerhans cells following exposure to dengue 2 (16681) virus. Southeast Asian J Trop Med Public Health 1996; 27 (4): 664-72.

36.- Wu S J, Grouard-Vogel G, Sun W, Mascola J R, Brachtel E, Putvatana R, et al. Human skin Langerhans cells are targets of dengue virus infection. Nat Med 2000; 6 (7): 816-20.

37.- Libraty D H, Pichyangkul S, Ajariyakhajorn C, Endy T P, Ennis F A. Human dendritic cells are activated by dengue virus infection: enhancement by gamma interferon and implications for disease pathogenesis. J Virol 2001; 75 (8): 3501-8.

38.- Ho L J, Wang J J, Shaio M F, Kao C L, Chang D M, Han S W, et al. Infection of human dendritic cells by dengue virus causes cell maturation and cytokine production. J Immunol 2001; 166 (3): 1499-506.

39.- Sun P, Fernández S, Marovich M A, Palmer D R, Celluzzi C M, Boonnak K, et al. Functional characterization of ex vivo blood myeloid and plasmacytoid dendritic cells after infection with dengue virus. Virology 2009; 383 (2): 207-15.

40.- Liu Y J. IPC: professional type 1 interferonproducing cells and plasmacytoid dendritic cell precursors. Annu Rev Immunol 2005; 23 : 275-306.

41.- Wang J P, Liu P, Latz E, Golenbock D T, Finberg R W, Libraty D H. Flavivirus activation of plasmacytoid dendritic cells delineates key elements of TLR7 signaling beyond endosomal recognition. J Immunol 2006; 177 (10): 711421.

42.- Decembre E, Assil S, Hillaire M L, Dejnirattisai W, Mongkolsapaya J, Screaton GR, et al. Sensing of immature particles produced by dengue virus infected cells induces an antiviral response by plasmacytoid dendritic cells. PLoS
Pathog 2014; 10 (10): e1004434.

43.- Pichyangkul S, Endy T P, Kalayanarooj S, Nisalak A, Yongvanitchit K, Green S, et al A blunted blood plasmacytoid dendritic cell response to an acute systemic viral infection is associated with increased disease severity. $\mathrm{J}$ Immunol 2003; 171 (10): 5571-8.

44.- Tsai Y T, Chang S Y, Lee C N, Kao C L. Human TLR3 recognizes dengue virus and modulates viral replication in vitro. Cell Microbiol 2009; 11 (4): 604-15.

45.- de Kruif M D, Setiati T E, Mairuhu A T, Koraka P, Aberson H A, Spek C A, et al. Differential gene expression changes in children with severe dengue virus infections. PLoS Negl Trop Dis 2008; 2 (4): e215.

46.- Torres S, Hernández J C, Giraldo D, Arboleda M, Rojas M, Smit J M, et al. Differential expression of Toll-like receptors in dendritic cells of patients with dengue during early and late acute phases of the disease. PLoS Negl Trop Dis 2012; 7 (2): e2060.

47.- Kyle J L, Beatty P R, Harris E. Dengue virus infects macrophages and dendritic cells in a mouse model of infection. J Infect Dis 2007; 195 (12): 1808-17.

48.- Tsai T T, Chuang Y J, Lin Y S, Chang C P, Wan S W, Lin S H, et al. Antibody-dependent enhancement infection facilitates dengue virus-regulated signaling of IL-10 production in monocytes. PLoS Negl Trop Dis 2014; 8 (11): e3320.

49.- Nimmerjahn F, Ravetch J V. Fcgamma receptors as regulators of immune responses. Nat Rev Immunol 2008; 8 (1): 34-47.

50.- Rodrigo W W, Jin X, Blackley S D, Rose R $\mathrm{C}$, Schlesinger J J. Differential enhancement of dengue virus immune complex infectivity mediated by signaling-competent and signalingincompetent human Fcgamma RIA (CD64) or FcgammaRIIA (CD32). J Virol 2006; 80 (20): 10128-38.

51.- Boonnak K, Slike B M, Burgess T H, Mason R M, Wu S J, Sun P, et al. Role of dendritic cells in antibody-dependent enhancement of dengue virus infection. J Virol 2008; 82 (8): 3939-51.

52.- Boonnak K, Slike B M, Donofrio G C, Marovich M A. Human FcgammaRII cytoplasmic domains differentially influence antibody-mediated dengue virus infection. J Immunol 2013; 190 (11): 5659-65.

53.- Liu Y, Gao X, Masuda E, Redecha P B, Blank M C, Pricop L. Regulated expression of FcgammaR in human dendritic cells controls cross-presentation of antigenantibody complexes. J Immunol 2006; 177 (12): 8440-7.

54.- Torres S, Flipse J, Upasani V C, van der EndeMetselaar H, Urcuqui-Inchima S, Smit J M, et al. Altered immune response of immature dendritic cells following dengue virus infection in the presence of specific antibodies. J Gen Virol 2016; 97 (7): 1584-91.

55.- Palmer D R, Sun P, Celluzzi C, Bisbing J, Pang S, Sun W, et al. Differential effects of dengue virus on infected and bystander dendritic cells. J Virol 2005; 79 (4): 2432-9.

56.- Martins Sde T, Silveira G F, Alves L R, Duarte dos Santos C N, Bordignon J. Dendritic cell apoptosis and the pathogenesis of dengue. Viruses 2012; 4 (11): 2736-53.

57.- Luplertlop N, Misse D, Bray D, Deleuze V, González J P, Leardkamolkarn V, et al. Dengue-virus-infected dendritic cells trigger vascular leakage through metalloproteinase overproduction. EMBO Rep 2006; 7 (11): 1176-81.

58.- Mathew A, Kurane I, Green S, Vaughn D W, Kalayanarooj S, Suntayakorn S, et al. Impaired $\mathrm{T}$ cell proliferation in acute dengue infection. $\mathrm{J}$ Immunol 1999; 162 (9): 5609-15.

59.- Sun P, Celluzzi C M, Marovich M, Subramanian H, Eller M, Widjaja S, et al. CD40 ligand enhances dengue viral infection of dendritic cells: a possible mechanism for T cellmediated immunopathology. J Immunol 2006; 177 (9): 6497-503.

60.- Dejnirattisai W, Duangchinda T, Lin C L, Vasanawathana S, Jones M, Jacobs M, et al. A complex interplay among virus, dendritic cells, T cells, and cytokines in dengue virus infections. J Immunol 2008; 181 (9): 5865-74.

61.- Luo D, Vasudevan S G, Lescar J. The flavivirus NS2B-NS3 protease-helicase as a target for antiviral drug development. Antiviral Res 2015; 118: $148-58$

62.- Luo D, Xu T, Hunke C, Gruber G, Vasudevan S G, Lescar J. Crystal structure of the NS3 protease-helicase from dengue virus. J Virol 2008; 82 (1): 173-83.

63.- Bera A K, Kuhn R J, Smith J L. Functional characterization of cis and trans activity of the Flavivirus NS2B-NS3 protease. J Biol Chem 2007; 282 (17): 12883-92.

64.- Miller S, Kastner S, Krijnse-Locker J, Buhler $\mathrm{S}$, Bartenschlager R. The non-structural protein $4 \mathrm{~A}$ of dengue virus is an integral membrane protein inducing membrane alterations in a 2K-regulated manner. J Biol Chem 2007; 282 (12): 8873-82

65.- Muñoz-Jordan J L, Sánchez-Burgos G G, Laurent-Rolle M, García-Sastre A. Inhibition of interferon signaling by dengue virus. Proc Natl Acad Sci U S A 2003; 100 (24): 14333-8.

66.- Lim S P, Noble C G, Shi P Y. The dengue virus NS5 protein as a target for drug discovery. Antiviral Res 2015; 119: 57-67.

67.- Ashour J, Laurent-Rolle M, Shi P Y, GarciaSastre A. NS5 of dengue virus mediates STAT2 binding and degradation. J Virol 2009; 83 (11): 5408-18. 